\title{
Curcumin causes DNA damage and affects associated protein expression in HeLa human cervical cancer cells
}

\author{
HUNG-SHENG SHANG $^{1 *}$, CHUAN-HSUN CHANG $^{2 *}$, YU-RU CHOU ${ }^{3}$, MING-YANG YEH $^{4}$, \\ MAN-KUAN AU ${ }^{5}$, HSU-FENG LU ${ }^{6}$, YUNG-LIN CHU ${ }^{7}$, HSIAO-MIN CHOU $^{8}$, HSIU-CHEN CHOU $^{8}$, \\ YUNG-LUEN SHIH ${ }^{8-10^{*}}$ and JING-GUNG CHUNG ${ }^{11,12^{*}}$
}

${ }^{1}$ Department of Pathology, National Defense Medical Center, Division of Clinical Pathology, Tri-Service General Hospital; Departments of ${ }^{2}$ Surgical Oncology, ${ }^{3}$ Nutrition Therapy, ${ }^{4}$ Office of Director, ${ }^{5}$ Orthopedics and ${ }^{6}$ Clinical Pathology, Cheng Hsin General Hospital, Taipei; ${ }^{7}$ International Master's Degree Program in Food Science, International College, National Pingtung University of Science and Technology, Pingtung; ${ }^{8}$ Department of Pathology and Laboratory Medicine,

Shin Kong Wu Ho-Su Memorial Hospital; ${ }^{9}$ School of Medical Laboratory Science and Biotechnology, Taipei Medical University, Taipei; ${ }^{10}$ School of Medicine, College of Medicine, Fu-Jen Catholic University, New Taipei City; ${ }^{11}$ Department of Biological Science and Technology, China Medical University;

${ }^{12}$ Department of Biotechnology, Asia University, Taichung, Taiwan, R.O.C.

Received March 17, 2016; Accepted July 21, 2016

DOI: $10.3892 / o r .2016 .5002$

\begin{abstract}
Cervical cancer is one of the most common cancers in women worldwide and it is a prominent cause of cancer mortality. Curcumin is one of the major compounds from Turmeric and has been shown to induce cytotoxic cell death in human cervical cancer cells. However, there is no study to show curcumin induced DNA damage action via the effect on the DNA damage and repair protein in cervical cancer cells in detail. In this study, we investigated whether or not curcumin induced cell death via DNA damage, chromatin condensation in human cervical cancer HeLa cells by using comet assay and DAPI staining, respectively, we found that curcumin induced cell death through the induction of DNA damage, and chromatin condensation. Western blotting and confocal laser microscopy examination were used to examine the effects of curcumin on protein expression associated with DNA damage, repair and translocation of proteins. We found that curcumin
\end{abstract}

Correspondence to: Professor Jing-Gung Chung, Department of Biological Science and Technology, China Medical University, 91 Hsueh-Shih Road, Taichung, Taiwan, R.O.C.

E-mail: jgchung@mail.cmu.edu.tw

Dr Yung-Luen Shih, Department of Pathology and Laboratory Medicine, Shin Kong Wu Ho-Su Memorial Hospital, 95 Wen-Chang Road, Shih-Lin, Taipei, Taiwan, R.O.C.

E-mail: t005524@ms.skh.org.tw

${ }^{*}$ Contributed equally

Key words: curcumin, DNA damage, comet assay, 4',6-diamidino-2-phenylindole dihydrochloride staining, human cervical cancer HeLa cells at $13 \mu \mathrm{M}$ increased the protein levels associated with DNA damage and repair, such as $\mathrm{O}^{6}$-methylguanine-DNA methyltransferase, early-onset breast cancer 1 (BRCA1), mediator of

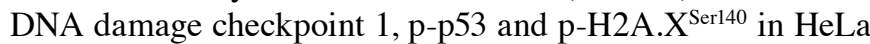
cells. Results from confocal laser systems microscopy indicated that curcumin increased the translocation of p-p53 and p-H2A.X $X^{\text {Ser140 }}$ from cytosol to nuclei in HeLa cells. In conclusion, curcumin induced cell death in HeLa cells via induction of DNA damage, and chromatin condensation in vitro.

\section{Introduction}

Cervical cancer is the seventh most common cancer overall in human populations and the second most common type of cancer in women in many developing countries (1-3). In Taiwan, cervical cancer is the tenth most common cause of cancer associated death with rates of 5.5/100,000 persons/year based on the 2012 report from the Department of Health, Executive Yuan, Taiwan. The treatments for cervical cancer include surgery, radiotherapy, chemotherapy or combination radiotherapy with chemotherapy. However, the reduction in quality of patients' life caused by the high toxic effects of chemotherapeutic drugs makes it unsatisfactory $(4,5)$. Numerous studies have been undertaken to find new therapies, mechanisms or compounds for cervical cancer treatment. Natural products have been used to treat cancer patients and those compounds can be used as complementary and/or alternative therapies in psychiatric medicine (6).

Curcumin is one of the plant pigments and was obtained from turmeric (Curcuma longa L.), which has been demonstrated to have wound healing function in diabetic animals (7), and anti-inflammatory (8), antibacterial (9) and antioxidant (10) properties. Furthermore, substantial evidence has shown that curcumin could be used as anti-carcinogenic substance through the inhibition of cell proliferation, inductions 
of cancer cell apoptosis, inhibition of angiogenesis and tumor metastasis (11-13). Curcumin has been shown to involve downregulation of nuclear factor- $\kappa \mathrm{B}$ and the serine/threonine kinase Akt and is independent of tubulin polymerization (14). Curcumin is safe to human in phase I clinical trials for up to $12 \mathrm{~g} /$ day orally and causes histologic improvement of precancerous lesions in some patients; thus it suggested that these doses of curcumin is biologically active $(15,16)$.

Several studies have shown that curcumin-mediated cell cycle arrest involved DNA damage signaling in colorectal carcinoma HCT116 cells (17), human bladder cancer T24 cells (18) and primary adult T-cell leukemia cells (19). It was reported that curcumin induced reactive oxygen species (ROS) production in human colon cancer HCT116 cells (20), nuclear DNA damage in human gastric mucosa cells, lymphocytes (21) and in human hepatoma HepG2 cells (22). Furthermore, there is no available information to show curcumin induced DNA damage in human cervical cancer cells and the exact nature of the trigger and the mechanisms involved are unclear.

Curcumin has been demonstrated to present antitumor activity against many types of human cancers (23-26). However, the inhibitory effects and possible mechanisms of curcumin induced DNA damage in human cervical cancer cells remain to be determined. Therefore, in this study, we used human cervical cancer HeLa cells to further characterize curcumin-induced DNA damage in vitro. Curcumin treatment generally resulted in decreased viable cells and DNA damage in vitro. We further investigated DNA damage associated protein expression and we found that curcumin inhibited DNA damage and repair associated proteins in HeLa cells.

\section{Materials and methods}

Chemicals and reagents. Curcumin, dimethyl sulfoxide (DMSO), propidium iodide (PI), trypsin-EDTA, penicillin-streptomycin, anti- $\mathrm{O}^{6}$-methylguanine-DNA methyltransferase (MGMT) (cat. no. M3068), anti-PARP (cat. no. P248), anti-p-ATMSer1981 (cat. no. SBA4300100) and anti- $\beta$-actin (cat. no. A5316) were purchased from Sigma Chemical Co. (St. Louis, MO, USA). Anti-DNA-PK (cat. no. PC127) was purchased from Calbiochem (San Diego, CA, USA). Anti-p-H2A.X (cat. no. GTX80694), anti-breast cancer 1 (BRCA1) (cat. no. GTX70111) and anti-MDM2 (cat. no. GTX110608) were purchased from GeneTex, Inc. (Irvine, CA, USA). Anti-mediator of DNA damage checkpoint 1 (MDC1) (cat. no. 05-1572) and anti-p53 (cat. no. 04-241) were purchased from Millipore Corp. (Billerica,

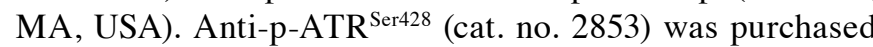
from Cell Signaling Technology, Inc. (Danvers, MA, USA). Dulbecco's modified Eagle's medium (DMEM) medium and fetal bovine serum (FBS) were purchased from Gibco ${ }^{\circledR}$, Invitrogen Life Technologies (Carlsbad, CA, USA). Curcumin was first dissolved in DMSO at $1 \mathrm{mM}$.

Cell culture. The human cervical cancer HeLa cell line was purchased from the Food Industry Research and Development Institute (Hsinchu, Taiwan). Cells were placed into $75 \mathrm{~cm}^{2}$ tissue culture flasks in DMEM medium supplemented with $10 \%$ FBS and $1 \%$ penicillin-streptomycin $(100 \mathrm{U} / \mathrm{ml}$ penicillin and $100 \mu \mathrm{g} / \mathrm{ml}$ streptomycin). Then cells were grown at $37^{\circ} \mathrm{C}$ in a humidified atmosphere of $95 \%$ air and $5 \% \mathrm{CO}_{2}$ as previously described $(27,28)$.

Cell morphology examination and cellular viability assay. HeLa cells $\left(1 \times 10^{5}\right.$ cells/well) were kept on the 12-well cell culture cluster overnight and then were treated with 0,12 , 13 and $14 \mu \mathrm{M}$ curcumin for $48 \mathrm{~h}$. After incubation, cells were examined by contrast-phase microscopy for cell morphological changes. Trypsin was added to the cells, harvested and rinsed three times with in phosphate-buffered saline (PBS). All cells were stained with PI $(5 \mu \mathrm{g} / \mathrm{ml})$ in PBS and the total percentage of cell viability was measured by flow cytometry (Becton-Dickinson, San Jose, CA, USA) as previously described (27).

Comet assay (single cell gel electrophoresis). HeLa cells

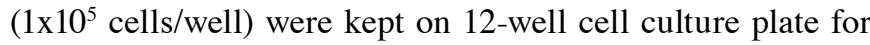
$24 \mathrm{~h}$ and then treated with $13 \mu \mathrm{M}$ of curcumin or $0.5 \% \mathrm{H}_{2} \mathrm{O}_{2}$ (positive control) for $0,6,24$ and $48 \mathrm{~h}$. At the end of incubation, aliquots of $10^{5}$ cells from each treatment were collected and cast into miniature LMA gels on microscope slides as previously described (27), followed by lysing in situ to relax the compacted DNA in nuclei of cells. Cells were electrophoresed and DNA was visualized and photographed by EB staining under fluorescence microscopy. Comets (DNA damage) of cells on slides were quantitated for comet tail lengths by the CometScore ${ }^{\mathrm{TM}}$ Freeware analysis (TriTek Corp., Sumerduck, VA, USA) (27).

4',6-Diamidino-2-phenylindole dihydrochloride (DAPI) staining. HeLa cells $\left(1.5 \times 10^{5}\right.$ cells/well) were maintained on 6 -well cell culture plate for $24 \mathrm{~h}$ and then were incubated with $13 \mu \mathrm{M}$ curcumin for $0,6,24$ and $48 \mathrm{~h}$. At the end of incubation, cells were fixed with $4 \%$ formaldehyde in PBS for $10 \mathrm{~min}$, followed by washing with PBS and then were stained by DAPI for $1 \mathrm{~h}$ at $37^{\circ} \mathrm{C}$. Cells from each treatment were examined and photographed by using a fluorescence microscope at x200 as previously described (27).

Apo-BrdU (bromolated deoxyuridine triphosphate nucleotides) TUNEL assays. To evaluate HeLa cell DNA fragmentation, the HeLa cells $\left(1.5 \times 10^{5}\right.$ cells/well) were maintained on 6 -well plate and treated with 0 and $13 \mu \mathrm{M}$ of curcumin for $0,12,24$ and $48 \mathrm{~h}$. Cells were fixed in $4 \%$ formaldehyde in PBS for $15 \mathrm{~min}$, and then washed twice with ice-cold PBS, and incubated in the dark for $60 \mathrm{~min}$ at $37^{\circ} \mathrm{C}$ in $50 \mu \mathrm{l}$ of DNA Labeling Solution each assay. TUNEL assays were performed by fluorescence microscope in triplicate on three independent experiments. TUNEL staining was performed according to the manufacturer's instructions (Apo-BrdU in situ DNA fragmentation assay kit; BioVision, Inc., Milpitas, CA, USA) (27).

Western blotting. HeLa cells $\left(1.5 \times 10^{6}\right.$ cells/dish) were maintained on a $10-\mathrm{cm}$ dish with DMEM medium containing $10 \%$ FBS for $24 \mathrm{~h}$ and were incubated with $13 \mu \mathrm{M}$ of curcumin for $0,6,24$ and $48 \mathrm{~h}$. After treatment, cells were collected and suspended in sodium dodecyl sulphate (SDS) buffer followed by sonication and boiling for $10 \mathrm{~min}$ as described previously (27). The total protein in each sample was quantitated. A total $30 \mu \mathrm{g}$ from each sample was electrophoresed by $10 \%$ SDS-polyacrylamide gel electrophoresis (SDS-PAGE), 
transferred to PVDF membrane, and were immunoblotted as previously described (27). Membranes were transferred, and then were followed by staining with primary antibodies such as anti-p-ATM, anti-p-ATR, anti-p53, anti-MDM2, and anti-p-p53, anti-BRCA1, anti-DNA-PK, anti-MDC1, anti-p-H2A.X, anti-PARP and anti-MGMT at $4^{\circ} \mathrm{C}$ (overnight), each membrane was then washed. After washing, all membranes were stained by secondary antibody, washed and were visualized with a chemiluminescent detection system and the protein expressions were quantitated as described by the manufacturer $(27,29)$.

Confocal laser microscopy. HeLa cells $\left(1.5 \times 10^{5}\right.$ cells/well) were maintained on 6 -well plate and treated with 0 and $13 \mu \mathrm{M}$ of curcumin for $48 \mathrm{~h}$. Cells were rinsed and fixed in $4 \%$ formaldehyde in PBS for $15 \mathrm{~min}$ as previously described (30). Cells were washed and permeablized with $0.1 \%$ Triton X-100 in PBS followed by washing and blocking with 5\% BSA in PBS for $60 \mathrm{~min}$ and then were washed with PBS. The primary anti-p-H2A.X, anti-p53 and anti-p-p53 (green fluorescence) were used to stain cells and then followed by secondary antibody (FITC-conjugated goat anti-mouse IgG) staining. The PI (red fluorescence) used for nuclei staining and were photomicrographed under a Leica TCS SP2 confocal spectral microscope as previously described (30).

Statistical analysis. All quantitative data were presented as the mean \pm standard deviation (SD) from three independent experiments. Student's t-test was used to compare means between the control and curcumin treated groups. The $\mathrm{P}<0.05$ was considered as the significant level.

\section{Results}

Curcumin induces cell morphological changes and decreases the total percentage of HeLa viable cells. HeLa cells were incubated with $0,12,13$ and $14 \mu \mathrm{M}$ curcumin for $48 \mathrm{~h}$ and then were examined for cell morphology and were collected for percentage of viable cell determinations and results are shown in Fig. 1A and B. The results from Fig. 1A indicated that curcumin induced cell morphological changes and the total viable cells were decreased when compared to control (without curcumin treatment).

Curcumin induces DNA damage of HeLa cells. Cells were incubated with $13 \mu \mathrm{M}$ curcumin for $0,6,24$ and $48 \mathrm{~h}$ and then collected for comet assay. Results from Fig. 2A and B demonstrated that $13 \mu \mathrm{M}$ curcumin induced comet tail (DNA damage) production from single cell electrophoresis when compared with control in HeLa cells (Fig. 2A). The longer the incubation time, the longer the comet tail length which indicated that DNA damage is time-dependent caused by curcumin in HeLa cells (Fig. 2B).

Curcumin induces chromatin condensation of HeLa cells. For further confirming whether or not curcumin decreased the total viable cells through apoptosis of HeLa cells, cells were incubated with $13 \mu \mathrm{M}$ of curcumin for $0,6,24$ and $48 \mathrm{~h}$, and were stained by DAPI to investigate the formation of chromatin condensation which were characterized by nuclear

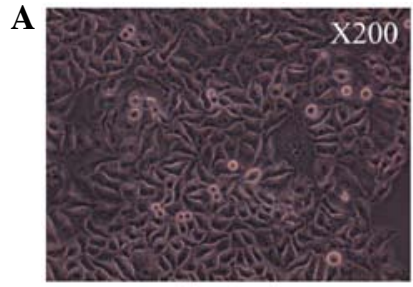

Control

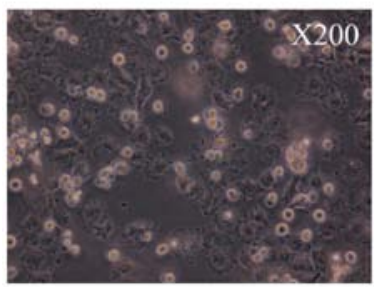

$13 \mu \mathrm{M}$

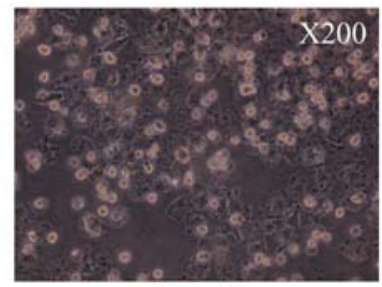

$12 \mu \mathrm{M}$

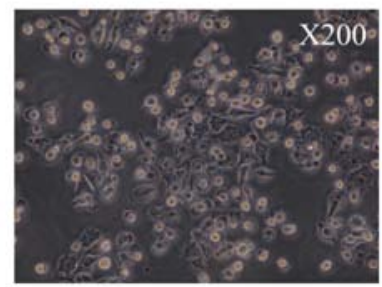

$14 \mu \mathrm{M}$
B

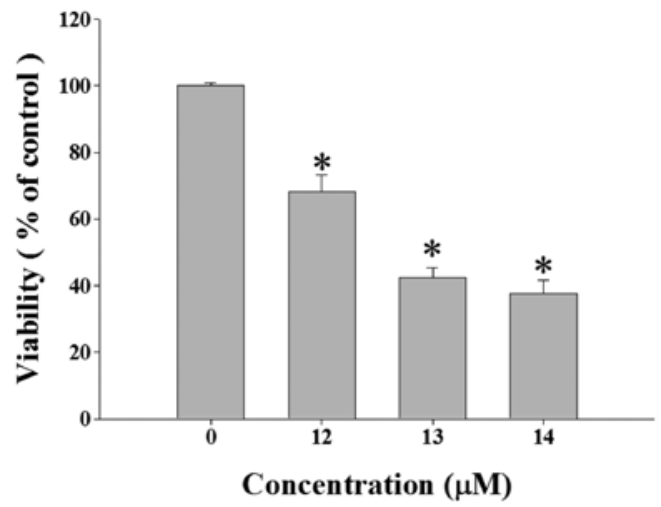

Figure 1. Curcumin induces cell morphological changes and decreases the percentage of viable human cervical cancer HeLa cells. Cells ( $1 \times 10^{5}$ cells/well $)$ were placed in 12-well plates and were incubated with $0,12,13$ and $14 \mu \mathrm{M}$ curcumin for $48 \mathrm{~h}$. (A) All samples were examined for cell morphology by contrast-phase microscopy at $\times 200$ magnification and (B) were stained with propidium iodide (PI) $(5 \mu \mathrm{g} / \mathrm{ml})$ to analyze the cell viability by flow cytometry as previously described. ${ }^{*} \mathrm{P}<0.05$ was considered significant.

fluorescence (white color). Results from Fig. 3A and B indicated that curcumin induced chromatin condensation in a time-dependent manner. The chromatin condensation was based on the higher fluoresence (DAPI staining) compared to control under fluorescence microscope examination in HeLa cells.

Curcumin induces DNA fragmentation of HeLa cells. HeLa cells were incubated with $13 \mu \mathrm{M}$ curcumin for 0,6 , 24 and $48 \mathrm{~h}$, and then collected for Apo-BrdU TUNEL assays. In order to investigate the expression of the BrdU in HeLa cells. Cells were exposed to $13 \mu \mathrm{M}$ of curcumin for 0,6 , 24 and $48 \mathrm{~h}$, and then were examined by confocal microscopy and results are shown in Fig. 4. Comparing with control group, the BrdU-FITC in cells treated with curcumin was found to increase the incorporation with DNA strand breaks and were visualized in the nucleus as shown in the Fig. 4 (merge image). The result demonstrated that curcumin induced DNA fragmentation that may be through the overexpression of BrdU in nuclei in HeLa cells.

Curcumin affects DNA damage associated proteins of HeLa cells. In order to further investigate curcumin induced DNA 
$\mathbf{A}$

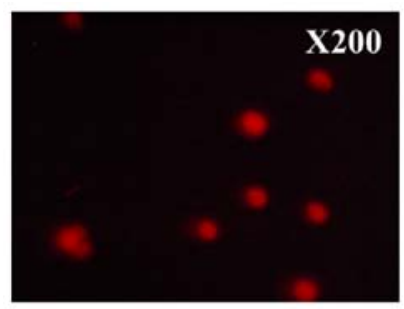

Control

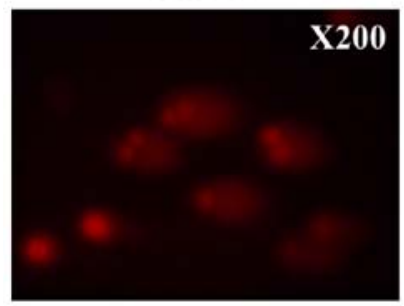

$6 \mathrm{~h}$

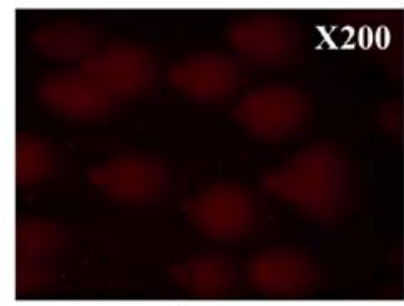

$\mathrm{H}_{2} \mathrm{O}_{2}$

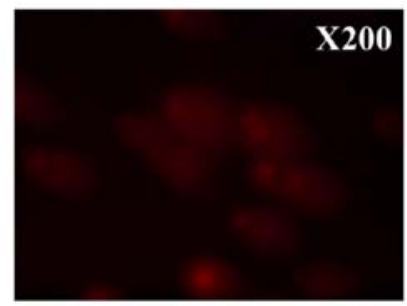

24 h

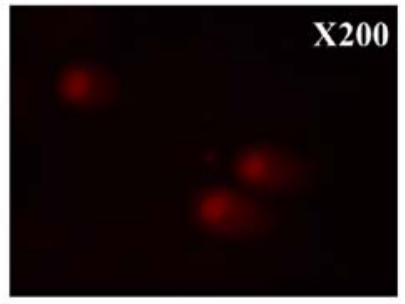

$48 \mathrm{~h}$

B

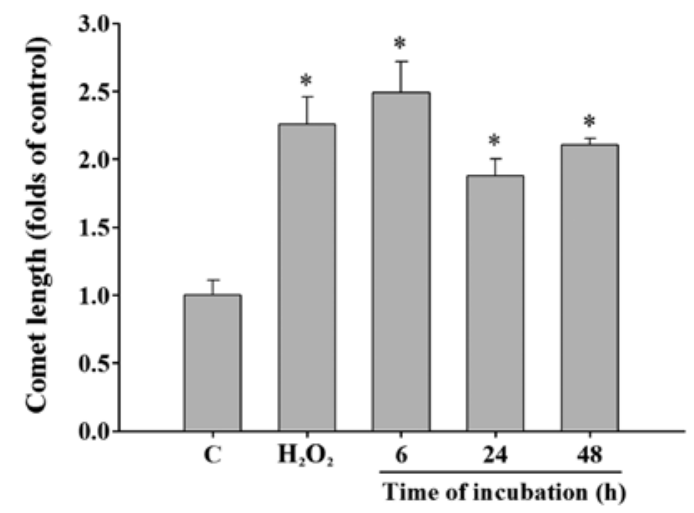

Figure 2. Curcumin-induced DNA damage in HeLa cells was measured by comet assay. Cells $\left(1 \times 10^{5}\right.$ cells/well) were placed in 12-well plates and then were incubated with $13 \mu \mathrm{M}$ curcumin for $0,6,24$ and $48 \mathrm{~h}$ and DNA damage was determined by comet assay, respectively as described in Materials and methods. (A) Representative picture of comet assay; (B) comet length (folds of control). Arrow showing the comet tail (DNA damage). "P $<0.05$ was considered significant.

A

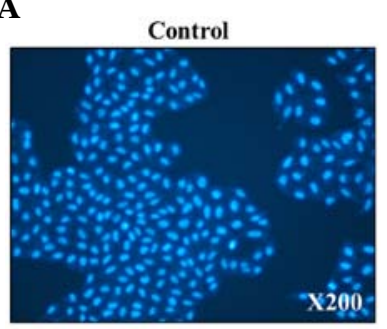

$24 \mathrm{~h}$

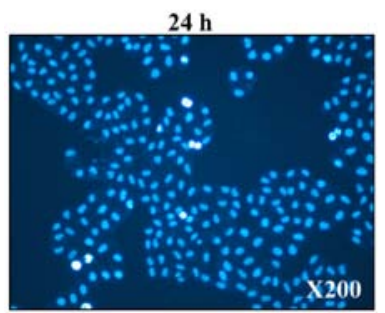

$6 \mathrm{~h}$

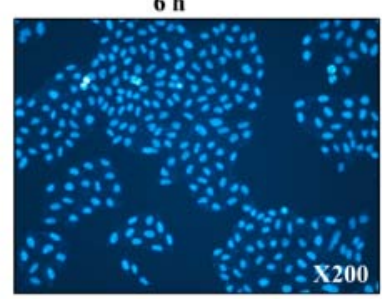

$48 \mathrm{~h}$

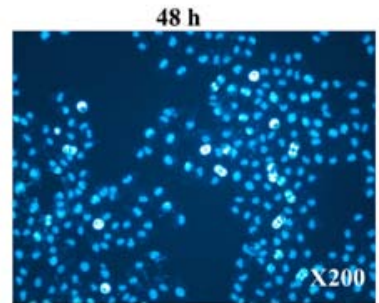

B

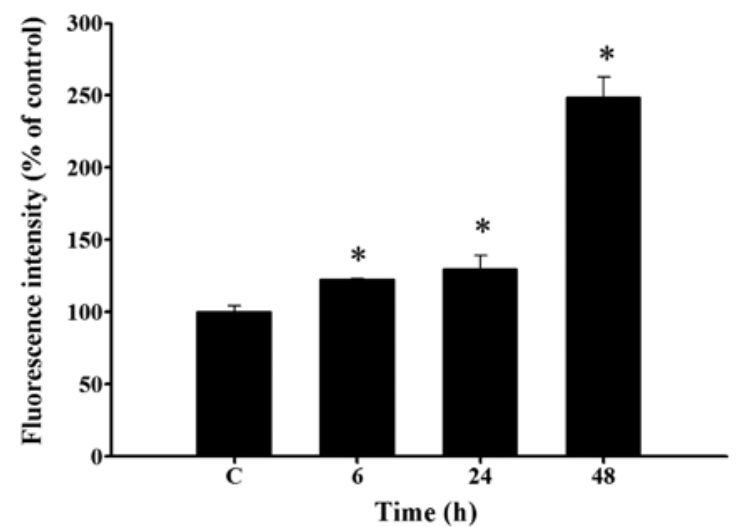

Figure 3. Curcumin-induced chromatin condensation in HeLa cells was examined by 4,6-diamidino-2-phenylindole dihydrochloride (DAPI) staining. Cells $\left(1.5 \times 10^{5}\right.$ cells/well) were placed in 6-well plates and were treated with $13 \mu \mathrm{M}$ curcumin for $0,6,24$ and $48 \mathrm{~h}$. Then cells in each treatment were DAPI stained as described in Materials and methods. (A) Cells were examined and photographed using a fluorescence microscope at x200 magnification. (B) Fluoresence intensity was calculated from each treatment. ${ }^{*} \mathrm{P}<0.05$ was considered significant.

damage via affect DNA damage and repair associated protein expression in HeLa cells, cells were treated with $13 \mu \mathrm{M}$ of curcumin for $0,6,24$ and $48 \mathrm{~h}$ and then total protein from cells were quantitated and DNA damage associated proteins were examined by western blotting and results are shown in Fig. 5A-C. These results demonstrated that curcumin significantly increased the amounts of proteins such as p-ATM, p-ATR, p53 and MDM2 (Fig. 5A), BRCA1, DNA-PK, MDC1 and p-H2A.X (Fig. 5B), PARP and MGMT (Fig. 5C) in HeLa cells. 


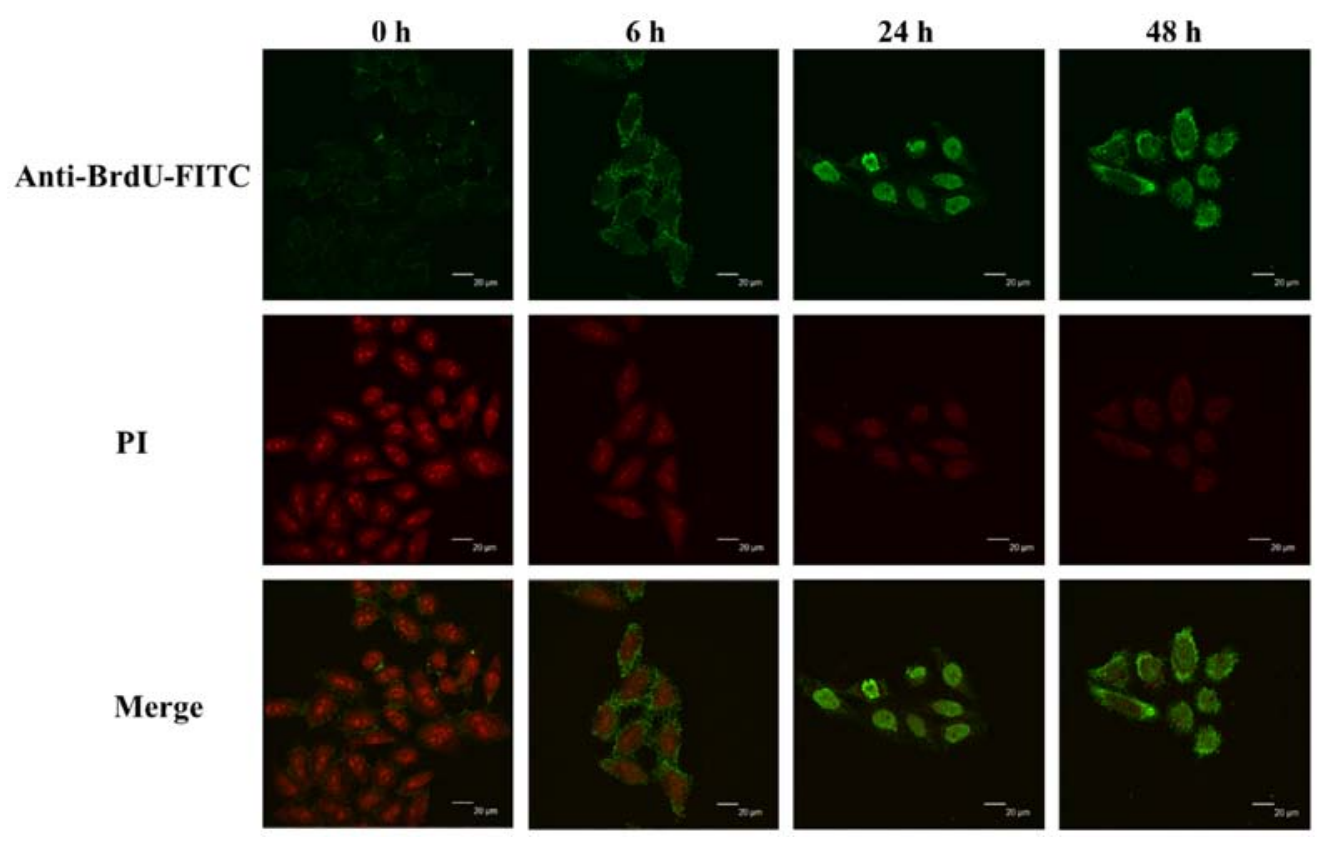

Figure 4. Curcumin affected the BrdU-FITC expression associated with DNA fragmentation in HeLa cells. Cells (5x10 ${ }^{4}$ cells/well) were placed on a 6-well plate, incubated with $13 \mu \mathrm{M}$ curcumin for $0,6,24$ and $48 \mathrm{~h}$ and then fixed in $4 \%$ formaldehyde in PBS for 15 min. After washing, cells were incubated with $0.1 \%$ Triton X-100 in PBS for $1 \mathrm{~h}$ and immunostaining by BrdU-FITC was performed as described in Materials and methods. Samples were examined and photo-micrographed under a Leica TCS SP2 confocal spectral microscope.

A

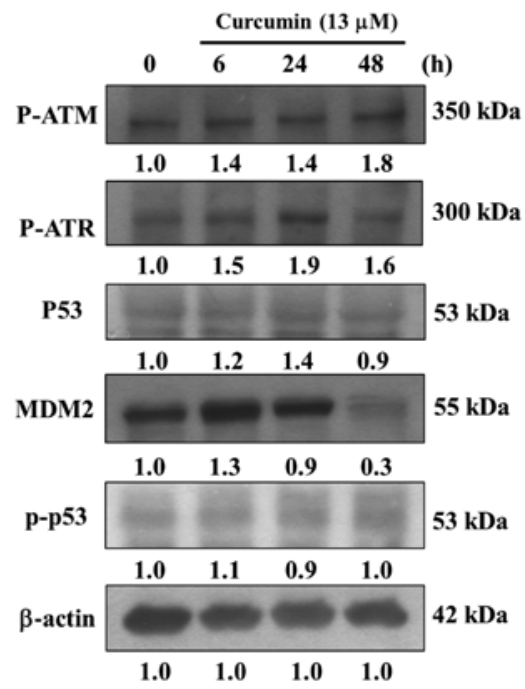

C

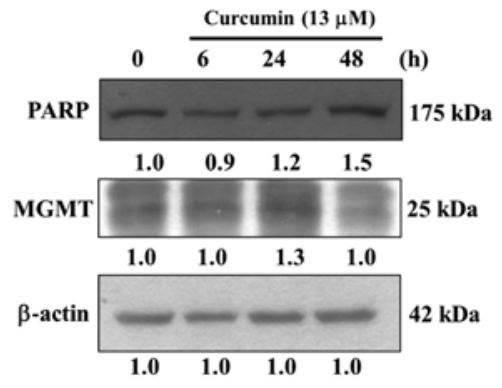

Curcumin affects the translocation of p53, p-p53 and p-H2A.X in HeLa cells. Based on the results from western blotting (Fig. 5A and B) indicated that curcumin increased the amounts of p53, p-p53 and p-H2A.X in HeLa cells, we investigated the translocation and increase of the proteins in HeLa cells. Cells were exposed to $13 \mu \mathrm{M}$ of curcumin for $48 \mathrm{~h}$

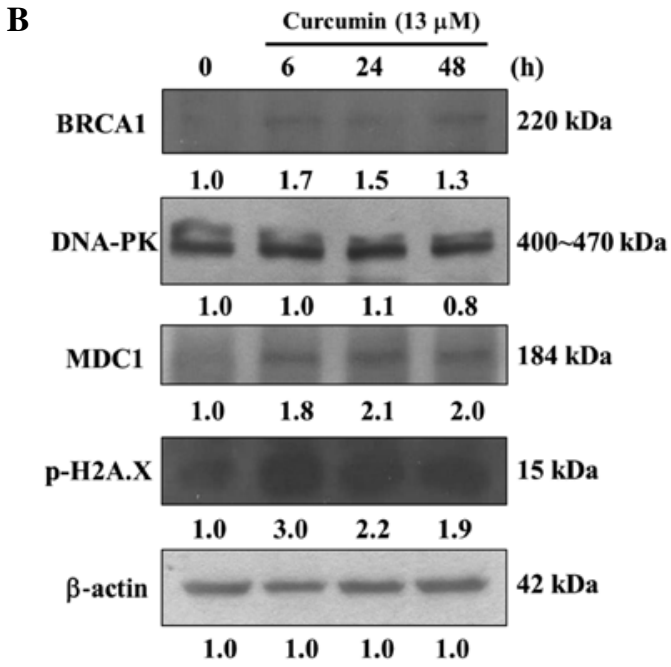

Figure 5. Curcumin affects the protein expression associated with DNA damage and repair in HeLa cells. Cells $\left(1.5 \times 10^{6}\right.$ cells/dish) were placed in $10-\mathrm{cm}$ dish and then incubated with $13 \mu \mathrm{M}$ curcumin for $0,6,24$ and $48 \mathrm{~h}$. The total proteins were collected and determined by Bio-Rad assay kit. The amounts of proteins from each treatment were examined by SDS-PAGE and immunoblotting as described in Materials and methods. (A) p-ATM, p-ATR, p53, MDM2, and p-p53; (B) BRCA1, DNA-PK, MDC1 and p-H2A.x; (C) PARP and MGMT.

and then examined by confocal microscopy and results are shown in Fig. 6. Contrasting to the control, the p53 (Fig. 6A), p-p53 (Fig. 6B) and p-H2A.X (Fig. 6C) in cells treated with curcumin was found to increase the cytosol, and more labelled p53, p-p53 and p-H2A.X were visualized in the nucleus as shown in the Fig. 6 (Merge image). These observations indi- 
A

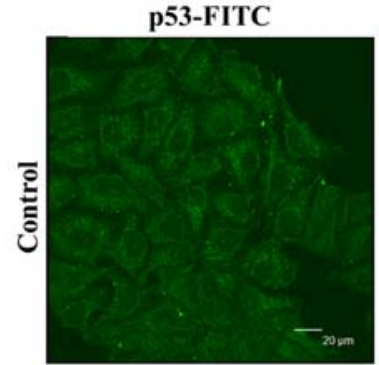

p53-FITC

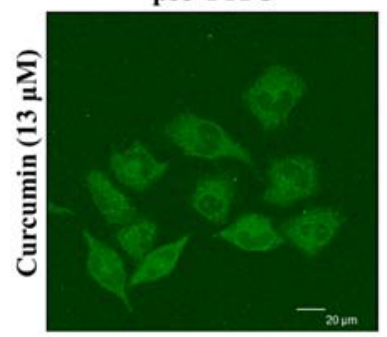

B

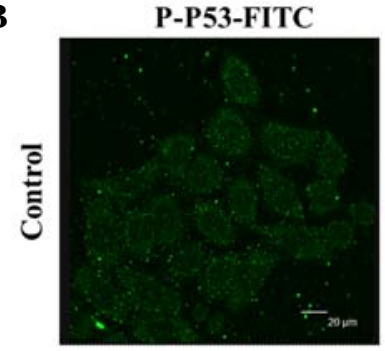

P-P53-FITC

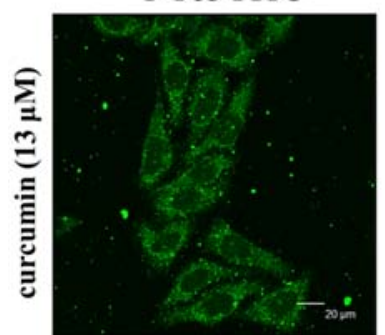

C

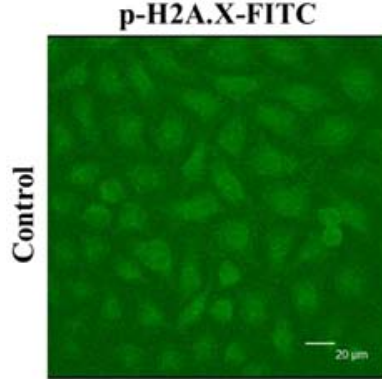

p-H2A.X-FITC

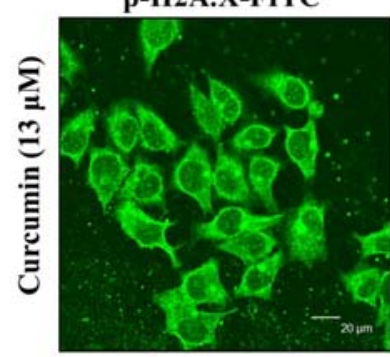

PI

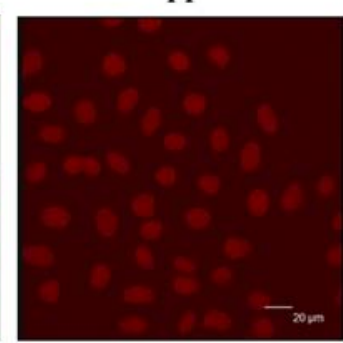

PI

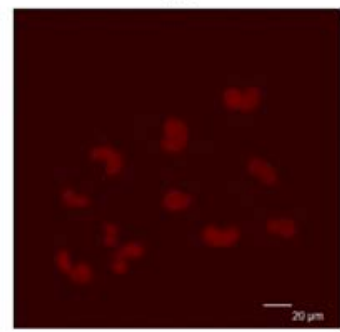

PI

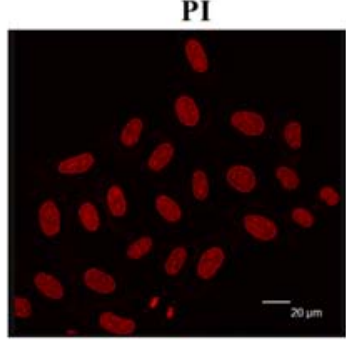

PI

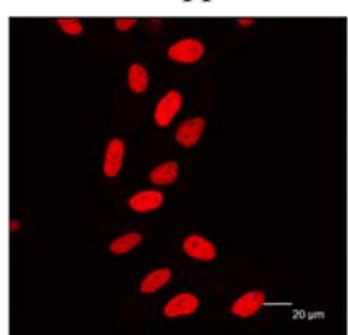

PI

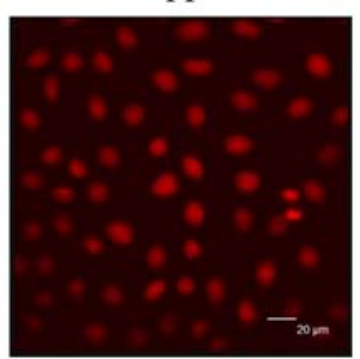

PI

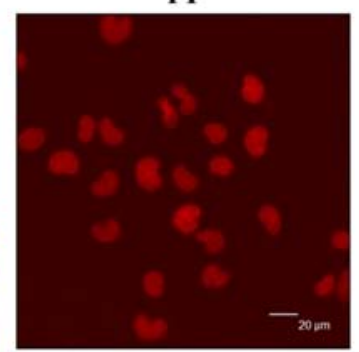

Merge

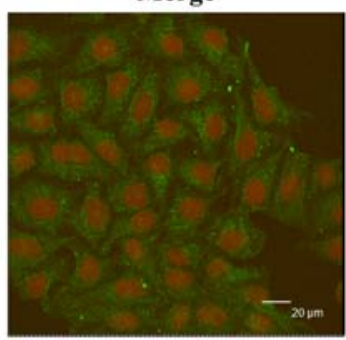

Merge

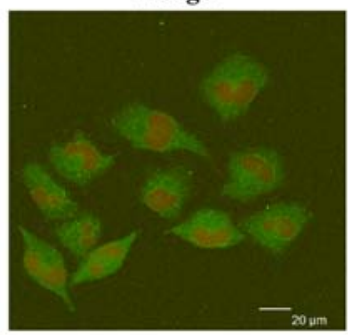

Merge

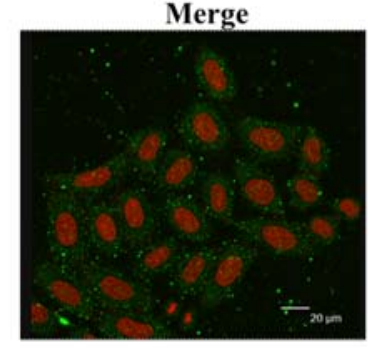

Merge

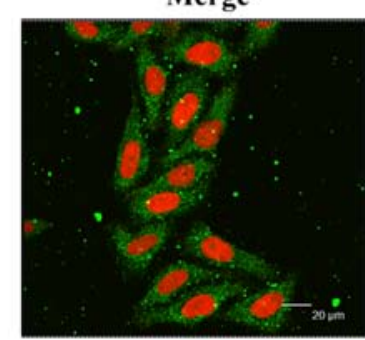

Merge

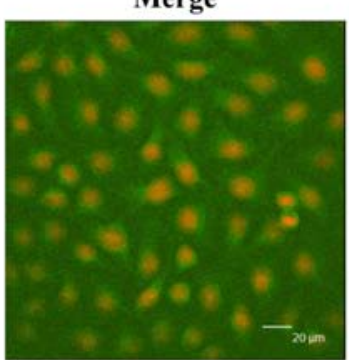

Merge

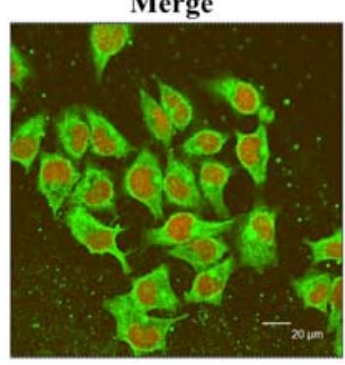

Figure 6. Curcumin affected the protein translocation in HeLa cells. Cells $\left(1.5 \times 10^{4}\right.$ cells/well) were placed on a 6 -well plate, incubated with $13 \mu \mathrm{M}$ curcumin for $48 \mathrm{~h}$ and then fixed in $4 \%$ formaldehyde in PBS for $15 \mathrm{~min}$. After washing, cells were incubated with $0.1 \%$ Triton X-100 in PBS for $1 \mathrm{~h}$ and immunostaining was performed as described in Materials and methods. (A) p53, (B) p-p53 and (C) p-H2A.X.. Both samples were examined and photo-micrographed under a Leica TCS SP2 confocal spectral microscope. 


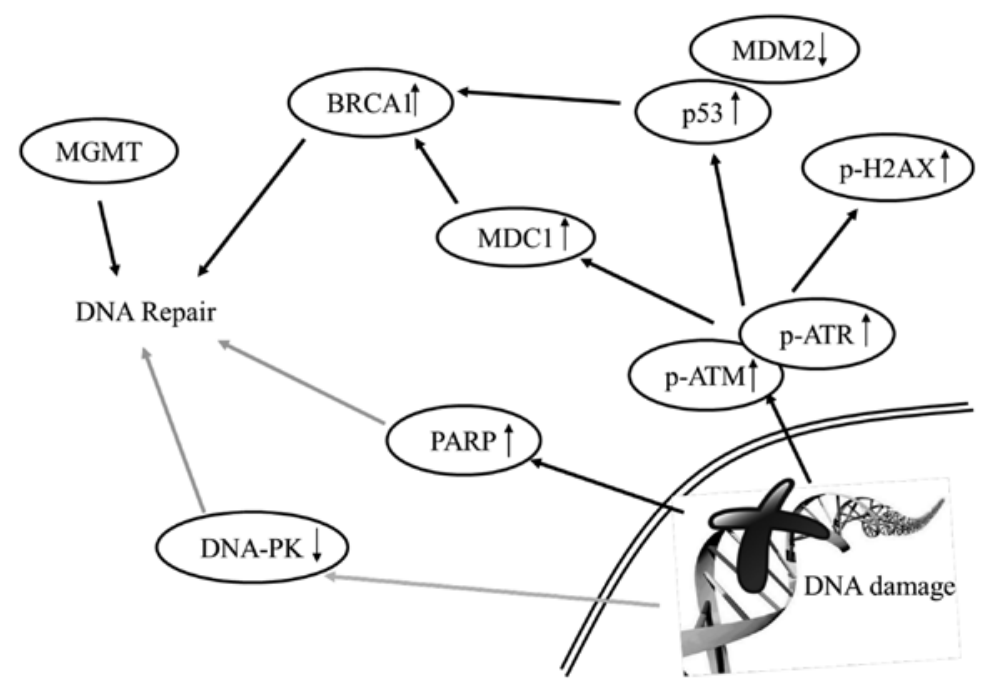

Figure 7. The proposed flow chart for curcumin-induced DNA damage and inhibition of DNA repair associated protein expression in human cervical cancer HeLa cells.

cated that curcumin induced DNA damage and repair that may be via the translocation of p53, p-p53 and p-H2A.X from cytoplasm into nuclei in HeLa cells.

\section{Discussion}

It is well documented that curcumin induced cell death may be via cell cycle arrest and induction of apoptosis in many human cancer cell lines, furthermore, animal studies revealed that oral administration of curcumin inhibited the incidence of cancers and it is under clinical trials to various cancers and related diseases (9). It was also reported that curcumin induced DNA damage and repair in several human cancer cells including human peripheral blood mononuclear cells (PBMCs) which was measured by the comet assay $(21,31)$. Recently, it was reported that curcumin can induce apoptosis of normal resting human $\mathrm{T}$ cells that is not connected with DNA damage (17). However, there is no available information to show curcumin induced DNA damage and affect DNA damage and repair associated protein expression in human cervical cancer cells. Therefore, we investigated whether or not curcumin induced DNA damage in HeLa cells and we found that: i) curcumin decreased the percentage of viable cells (Fig. 1); ii) a time-dependent increase in DNA damage was measured by comet assay (Fig. 2); iii) curcumin induced chromatin condensation time-dependently which was examined by DAPI staining (Fig. 3); iv) curcumin induced DNA fragmentation which was examined by TUNEL assay (Fig. 4); v) curcumin significantly increased p-ATM, p-ATR, p53 and MDM2 (Fig. 5A), BRCA1, MDC1 and p-H2A.X (Fig. 5B), PARP and MGMT (Fig. 5C) in HeLa cells; and vi) curcumin induced DNA damage and repair that may also involve p53, p-p53 and p-H2A.X (Fig. 6) translocation from cytoplasm into nuclei that were measured by confocal laser microscopy in HeLa cells.

Several studies have shown that curcumin induced DNA damage in cancer cells (32). Herein, we also showed that curcumin induced DNA damage (Fig. 3) and chromatin condensation (Fig. 2) in HeLa cells. Both were assayed by single cell electrophoresis (comet assay) and DAPI staining, respectively. Both assays are well known for measuring DNA damage $(32,33)$ and chromatin condensation $(34,35)$, respectively. There are studies that cells can repair DNA damage from agent induction and also can use DNA repair systems to eliminate these damaged DNA even to repair DNA base for cell maintaining survival $(36,37)$. In addition, previous studies showed that DNA fragmentation was closely related with apoptosis $(27,38)$. Our result showed that curcumin induced DNA fragmentation in Fig. 4 as well. The above descriptions indicated that curcumin could inhibit HeLa cell proliferation by induced DNA damage.

Results from western blotting indicated that curcumin increased DNA damage and repair associated protein expression such as p-ATM, p-ATR, p53 and MDM2 (Fig. 5A), BRCA1, MDC1 and p-H2A.X (Fig. 5B), PARP and MGMT (Fig. 5C), however, the protein levels of p-p53 (Fig. 5A) and DNA-PK (Fig. 5B) were no significantly affected. It was reported that MGMT in human cervical cancer $(39,40)$ and polymorphism in MGMT increases the susceptibility of women to cervical carcinoma (40), herein; we found that curcumin inhibited the expression of MGMT in HeLa cells (Fig. 5). It was reported that inhibiting MGMT could increase tumor susceptibility (41). MGMT can repair the pre-mutagenic, pre-carcinogenic and pre-toxic DNA damage $\mathrm{O}^{6}$-methylguanine (42) and MGMT has been recognized as an important change that takes place in cervical cancer (43).

BRCA1, is a tumor-suppressor gene, whose mutation has been correlated with the appearance of breast and/or ovarian cancer. Herein, we found that curcumin increased the expression of BRCA1 in HeLa cells (Fig. 5B). The BRCA1 gene products have been demonstrated to be associated with DNA damage repair, transcriptional control, cell growth, and apoptosis $(44,45)$. NSCLC patients with reduced BRCAl mRNA expression levels have greater overall survival benefit (46). Numerous studies have reported that MDC1 plays important roles in DNA damage response pathway (47) and have been shown also in human cervical cancer (48). Our findings showed that curcumin increased MDC1 expression in HeLa 
cells (Fig. 5B). Recently, it was reported that MDC1 seems to be related to the oncogenic potential of cervical cancer, furthermore, the suppression of its expression can inhibit cancer cell growth (48) and MDC1 could be a potential therapeutic target in human cervical cancer.

Fig. 5 shows that curcumin increased p53, p-p53 and p-H2A.X, respectively, in HeLa cells. We also used confocal laser microscopy to measure the translocation of p53 (Fig. 6A), p-p53 (Fig. 6B) and p-H2A.X (Fig. 6C) from cytoplasm to nuclei. It is well known that after DNA damage is present in cells, the protein level of p53 (a transcription factor) will increase. The p53 have been shown to mediate $G_{1}$ arrest for cells in response to genotoxic stress and allowing time for DNA repair (49). Herein, we found p53 was increased but p-p53 was not significantly increased. The phosphorylation of p53 has been shown to be the one type of upstream signal for triggering the p53 regulatory functions (50). The phospho-H2A.X, is a reliable marker of DNA double-strand breaks (DSBs) (51) and the H2A.X deficient mice will have higher radiosensitivity (52). In the present studies, we found that curcumin increased the expression of p-H2A.X (Fig. 6C) that was also confirmed by confocal laser microscopic examination (Fig. 6).

In conclusion, the results of the present study indicate that: i) curcumin induced cytotoxic effects (cell death) in HeLa cells; ii) curcumin induced DNA damage and cell death which were measured by comet assay and DAPI staining, respectively, in HeLa cells; and iii) curcumin increased the proteins levels of p-ATM, p-ATR, MGMT, BRCA1, MDC1, p53, p-p53 and p-H2A.X that may lead to cell death in HeLa cells as summarized in Fig. 7.

\section{Acknowledgements}

This study was supported by the grant no. 103-47 from the Cheng Hsin General Hospital (Taipei, Taiwan). Experiments and data analysis were performed in part through the use of the Medical Research Core Facilities Center, Office of Research and Development at China Medical University, Taichung, Taiwan.

\section{References}

1. Bray F, Jemal A, Grey N, Ferlay J and Forman D: Global cancer transitions according to the Human Development Index (2008-2030): A population-based study. Lancet Oncol 13: 790-801, 2012

2. Ding Y, Yang M, She S, Min H, Xv X, Ran X, Wu Y, Wang W, Wang L, Yi L, et al: iTRAQ-based quantitative proteomic analysis of cervical cancer. Int J Oncol 46: 1748-1758, 2015.

3. Smith HO, Tiffany MF, Qualls CR and Key CR: The rising incidence of adenocarcinoma relative to squamous cell carcinoma of the uterine cervix in the United States - a 24-year population-based study. Gynecol Oncol 78: 97-105, 2000.

4. Gascoigne KE and Taylor SS: Cancer cells display profound intra- and interline variation following prolonged exposure to antimitotic drugs. Cancer Cell 14: 111-122, 2008.

5. Rein DT and Kurbacher CM: The role of chemotherapy in invasive cancer of the cervix uteri: Current standards and future prospects. Anticancer Drugs 12: 787-795, 2001.

6. Chiappedi $M$ and Bejor $M$ : Herbals and natural dietary supplements in psychiatric practice. Recent Patents CNS Drug Discov 5: 164-171, 2010.

7. Sidhu GS, Mani H, Gaddipati JP, Singh AK, Seth P, Banaudha KK, Patnaik GK and Maheshwari RK: Curcumin enhances wound healing in streptozotocin induced diabetic rats and genetically diabetic mice. Wound Repair Regen 7: 362-374, 1999.
8. Niederau C and Göpfert E: The effect of chelidonium- and turmeric root extract on upper abdominal pain due to functional disorders of the biliary system. Results from a placebo-controlled double-blind study. Med Klin (Munich) 94: 425-430, 1999 (In German).

9. Duvoix A, Blasius R, Delhalle S, Schnekenburger M, Morceau F, Henry E, Dicato M and Diederich M: Chemopreventive and therapeutic effects of curcumin. Cancer Lett 223: 181-190, 2005.

10. Thiagarajan R and Manikandan R: Antioxidants and cataract. Free Radic Res 47: 337-345, 2013.

11. Basnet $P$ and Skalko-Basnet N: Curcumin: An anti-inflammatory molecule from a curry spice on the path to cancer treatment. Molecules 16: 4567-4598, 2011.

12. Kunnumakkara AB, Anand P and Aggarwal BB: Curcumin inhibits proliferation, invasion, angiogenesis and metastasis of different cancers through interaction with multiple cell signaling proteins. Cancer Lett 269: 199-225, 2008.

13. Shehzad A, Wahid F and Lee YS: Curcumin in cancer chemoprevention: Molecular targets, pharmacokinetics, bioavailability, and clinical trials. Arch Pharm (Weinheim) 343: 489-499, 2010.

14. Bava SV, Puliappadamba VT, Deepti A, Nair A, Karunagaran D and Anto RJ: Sensitization of taxol-induced apoptosis by curcumin involves down-regulation of nuclear factor-kappaB and the serine/threonine kinase Akt and is independent of tubulin polymerization. J Biol Chem 280: 6301-6308, 2005.

15. Goel A, Kunnumakkara AB and Aggarwal BB: Curcumin as 'Curecumin': From kitchen to clinic. Biochem Pharmacol 75: 787-809, 2008.

16. Strimpakos AS and Sharma RA: Curcumin: Preventive and therapeutic properties in laboratory studies and clinical trials. Antioxid Redox Signal 10: 511-545, 2008.

17. Lu JJ, Cai YJ and Ding J: Curcumin induces DNA damage and caffeine-insensitive cell cycle arrest in colorectal carcinoma HCT116 cells. Mol Cell Biochem 354: 247-252, 2011.

18. Park C, Kim GY, Kim GD, Choi BT, Park YM and Choi YH: Induction of $\mathrm{G} 2 / \mathrm{M}$ arrest and inhibition of cyclooxygenase-2 activity by curcumin in human bladder cancer T24 cells. Oncol Rep 15: 1225-1231, 2006.

19. Tomita M, Kawakami H, Uchihara JN, Okudaira T, Masuda M, Takasu N, Matsuda T, Ohta T, Tanaka Y, Ohshiro K, et al: Curcumin (diferuloylmethane) inhibits constitutive active NF-kappaB, leading to suppression of cell growth of human T-cell leukemia virus type I-infected T-cell lines and primary adult T-cell leukemia cells. Int J Cancer 118: 765-772, 2006.

20. Giri AK, Das SK, Talukder G and Sharma A: Sister chromatid exchange and chromosome aberrations induced by curcumin and tartrazine on mammalian cells in vivo. Cytobios 62: 111-117, 1990.

21. Blasiak J, Trzeciak A and Kowalik J: Curcumin damages DNA in human gastric mucosa cells and lymphocytes. J Environ Pathol Toxicol Oncol 18: 271-276, 1999.

22. Cao J, Jia L, Zhou HM, Liu Y and Zhong LF: Mitochondrial and nuclear DNA damage induced by curcumin in human hepatoma G2 cells. Toxicol Sci 91: 476-483, 2006.

23. Kim B, Kim HS, Jung EJ, Lee JY, K Tsang B, Lim JM and Song YS: Curcumin induces ER stress-mediated apoptosis through selective generation of reactive oxygen species in cervical cancer cells. Mol Carcinog 55: 918-928, 2015.

24. Lewinska A, Adamczyk J, Pajak J, Stoklosa S, Kubis B, Pastuszek P, Slota E and Wnuk M: Curcumin-mediated decrease in the expression of nucleolar organizer regions in cervical cancer (HeLa) cells. Mutat Res Genet Toxicol Environ Mutagen 771: 43-52, 2014.

25. Singh $M$ and Singh N: Molecular mechanism of curcumin induced cytotoxicity in human cervical carcinoma cells. Mol Cell Biochem 325: 107-119, 2009.

26. Sreekanth CN, Bava SV, Sreekumar E and Anto RJ: Molecular evidences for the chemosensitizing efficacy of liposomal curcumin in paclitaxel chemotherapy in mouse models of cervical cancer. Oncogene 30: 3139-3152, 2011.

27. Huang AC, Lin TP, Weng YS, Ho YT, Lin HJ, Huang LJ, Kuo SC and Chung JG: Ethyl 2-[N-m-chlorobenzyl-(2'-methyl)] anilino-4-oxo-4,5-dihydrofuran-3-carboxylate (JOT01006) induces apoptosis in human cervical cancer HeLa cells. Anticancer Res 27: 2505-2514, 2007.

28. Leung YM, Wong KL, Chen SW, Lu DY, Kuo CS, Chen YR, Chen YW and Cheng TH: Down-regulation of voltage-gated $\mathrm{Ca}^{2+}$ channels in $\mathrm{Ca}^{2+}$ store-depleted rat insulinoma RINm5F cells. Biomedicine 3: 130-139, 2013. 
29. Lin MC, Tsai SY, Wang FY, Liu FH, Syu JN and Tang FY: Leptin induces cell invasion and the upregulation of matrilysin in human colon cancer cells. Biomedicine 3: 174-180, 2013.

30. Wu LY, Lu HF, Chou YC, Shih YL, Bau DT, Chen JC, Hsu SC and Chung JG: Kaempferol induces DNA damage and inhibits DNA repair associated protein expressions in human promyelocytic leukemia HL-60 cells. Am J Chin Med 43: 365-382, 2015.

31. Błasiak J, Trzeciak A, Małecka-Panas E, Drzewoski J, Iwanienko T, Szumiel I and Wojewódzka M: DNA damage and repair in human lymphocytes and gastric mucosa cells exposed to chromium and curcumin. Teratog Carcinog Mutagen 19: 19-31, 1999.

32. Ashby J, Tinwell H, Lefevre PA and Browne MA: The single cell gel electrophoresis assay for induced DNA damage (comet assay): Measurement of tail length and moment. Mutagenesis 10: 85-90, 1995.

33. Pool-Zobel BL, Lotzmann N, Knoll M, Kuchenmeister F, Lambertz R, Leucht U, Schröder HG and Schmezer P: Detection of genotoxic effects in human gastric and nasal mucosa cells isolated from biopsy samples. Environ Mol Mutagen 24: 23-45, 1994.

34. Marchissio MJ, Francés DE, Carnovale CE and Marinelli RA: Evidence for necrosis, but not apoptosis, in human hepatoma cells with knockdown of mitochondrial aquaporin-8. Apoptosis 19: 851-859, 2014

35. Zheng B, Wu L, Ma L, Liu S, Li L, Xie W and Li X: Telekin induces apoptosis associated with the mitochondria-mediated pathway in human hepatocellular carcinoma cells. Biol Pharm Bull 36: 1118-1125, 2013.

36. Olive PL, Banáth JP and Durand RE: Detection of etoposide resistance by measuring DNA damage in individual Chinese hamster cells. J Natl Cancer Inst 82: 779-783, 1990.

37. Tice RR, Andrews PW and Singh NP: The single cell gel assay: A sensitive technique for evaluating intercellular differences in DNA damage and repair. Basic Life Sci 53: 291-301, 1990.

38. Malhotra P, Adhikari M, Singh SK and Kumar R: N-acetyl tryptophan glucopyranoside (NATG) provides radioprotection to murine macrophage J774A.1 cells. Free Radic Res 49: $1488-1498,2015$

39. Banzai C, Nishino K, Quan J, Yoshihara K, Sekine M, Yahata T and Tanaka K; Gynecological Cancer Registry of Niigata: Promoter methylation of DAPK1, FHIT, MGMT, and CDKN2A genes in cervical carcinoma. Int J Clin Oncol 19: 127-132, 2014.

40. Huang J, Ye F, Chen H, Lu W and Xie X: Amino acid substitution polymorphisms of the DNA repair gene $M G M T$ and the susceptibility to cervical carcinoma. Carcinogenesis 28: 1314-1322, 2007.

41. Verbeek B, Southgate TD, Gilham DE and Margison GP $\mathrm{O}^{6}$-Methylguanine-DNA methyltransferase inactivation and chemotherapy. Br Med Bull 85: 17-33, 2008.
42. Christmann M, Verbeek B, Roos WP and Kaina B: $\mathrm{O}(6)$-Methylguanine-DNA methyltransferase (MGMT) in normal tissues and tumors: Enzyme activity, promoter methylation and immunohistochemistry. Biochim Biophys Acta 1816: 179-190, 2011.

43. Dueñas-González A, Lizano M, Candelaria M, Cetina L, Arce C and Cervera E: Epigenetics of cervical cancer. An overview and therapeutic perspectives. Mol Cancer 4: 38, 2005.

44. Abramovitch S, Glaser T, Ouchi T and Werner H: BRCA1-Sp1 interactions in transcriptional regulation of the IGF-IR gene. FEBS Lett 541: 149-154, 2003.

45. Maor SB, Abramovitch S, Erdos MR, Brody LC and Werner H: BRCA1 suppresses insulin-like growth factor-I receptor promoter activity: Potential interaction between BRCA1 and Sp1. Mol Genet Metab 69: 130-136, 2000.

46. Taron M, Rosell R, Felip E, Mendez P, Souglakos J, Ronco MS, Queralt C, Majo J, Sanchez JM, Sanchez JJ, et al: BRCAl mRNA expression levels as an indicator of chemoresistance in lung cancer. Hum Mol Genet 13: 2443-2449, 2004.

47. Lou Z, Minter-Dykhouse K, Franco S, Gostissa M, Rivera MA, Celeste A, Manis JP, van Deursen J, Nussenzweig A, Paull TT, et al: MDC1 maintains genomic stability by participating in the amplification of ATM-dependent DNA damage signals. Mol Cell 21: 187-200, 2006.

48. Amichay K, Kidron D, Attias-Geva Z, Schayek H, Sarfstein R, Fishman A, Werner $\mathrm{H}$ and Bruchim I: BRCA1 is expressed in uterine serous carcinoma (USC) and controls insulin-like growth factor I receptor (IGF-IR) gene expression in USC cell lines. Int J Gynecol Cancer 22: 748-754, 2012.

49. Prives C and Hall PA: The p53 pathway. J Pathol 187: $112-126,1999$.

50. Gorgoulis VG, Zacharatos P, Mariatos G, Liloglou T, Kokotas S, Kastrinakis N, Kotsinas A, Athanasiou A, Foukas P, Zoumpourlis V, et al: Deregulated expression of c-mos in non-small cell lung carcinomas: Relationship with $p 53$ status, genomic instability, and tumor kinetics. Cancer Res 61: 538-549, 2001

51. Bonner WM, Redon CE, Dickey JS, Nakamura AJ, Sedelnikova OA, Solier S and Pommier Y: GammaH2AX and cancer. Nat Rev Cancer 8: 957-967, 2008.

52. Celeste A, Petersen S, Romanienko PJ, Fernandez-Capetillo O, Chen HT, Sedelnikova OA, Reina-San-Martin B, Coppola V, Meffre E, Difilippantonio MJ, et al: Genomic instability in mice lacking histone H2AX. Science 296: 922-927, 2002. 